\title{
The CFTR 3849+10kbC->T and
}

\section{$2789+5 \mathrm{G}->$ A alleles are associated with a} mild CF phenotype

\author{
I. Duguépéroux and M. De Braekeleer
}

ABSTRACT: Most cystic fibrosis (CF) transmembrane receptor mutations are rare. The French CF Registry offers an opportunity to study the genotype-phenotype relationship of these rare alleles. Since 1992, $39 \mathrm{CF}$ patients carrying one copy of the $3849+10 \mathrm{kbC}->\mathrm{T}$ mutation and 88 the 2789+5G- $>$ A allele have been seen at least once in a CF care centre. Among them, 16 carrying the $3849+10 \mathrm{kbC}->\mathrm{T} / \Delta \mathrm{F} 508$ genotype and 34 with the $2789+5 \mathrm{G}->\mathrm{A} / \Delta \mathrm{F} 508$ genotype were seen in 2000. Their age at diagnosis, sweat chloride concentration, anthropometric and lung function results, and clinical aspects were compared with those homozygous for the $\Delta F 508$ mutation matched for sex, age and CF care centre.

Major differences, most of them statistically significant, in the age at diagnosis, prevalence of pancreatic insufficiency, and other clinical signs, anthropometric and lung function measures were observed between both compound heterozygote groups and their matched $\Delta F 508 / \Delta F 508$ groups. The mean sweat chloride concentration was also lower (close to normal values) among $3849+10 \mathrm{kbC}->\mathrm{T} / \Delta \mathrm{F} 508$ patients, but not among $2789+5 \mathrm{G}->\mathrm{A} / \Delta \mathrm{F} 508$ patients.

In conclusion, both mutations studied here are associated with a milder course of cystic fibrosis disease. The $3849+10 \mathrm{kbC}->\mathrm{T}$ and $2789+5 \mathrm{G}->\mathrm{A}$ alleles are splice site mutations, leading to abnormal mRNA; however, a small amount of normally spliced transcripts can also be detected. The presence of these small amounts of normal cystic fibrosis transmembrane receptor protein in these cystic fibrosis patients is likely to be responsible for the milder severity of disease and a better life expectancy.

KEYWORDS: Cystic fibrosis, genotype-phenotype, mild allele, 3849+10kbC- $>$ T, 2789+5G- $>$ A

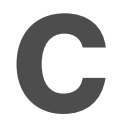
ystic fibrosis (CF) is the most common inherited disorder in Caucasian populations. It is characterised by a chronic and progressive obstructive lung disease, pancreatic insufficiency and high sweat electrolyte levels. Despite being a monogenic disease, CF appears to be very heterogeneous. Indeed, since the cystic fibrosis transmembrane conductance regulator (CFTR) gene was cloned in 1989, >1,300 mutations have been described [1-3]. Moreover, the distribution of these CFTR mutations ranges widely between countries and/or ethnic groups [4].

Several attempts have been made to correlate the phenotype of CF disease with the genotype among patients sharing the same mutations [58]. However, since most of the mutations have a low frequency, multi-centre studies are needed to investigate their relationship with CF phenotype. The French CF registry, which annually performs a survey of the patients followed in French CF centres, offers such an opportunity [9]. This study reports the results of a genotype-phenotype correlation analysis for two rare and mild mutations $(3849+10 \mathrm{kbC}->\mathrm{T}$ and $2789+5 \mathrm{G}->\mathrm{A})$.

\section{MATERIALS AND METHODS}

Since 1992, the French CF registry has collected and analysed data from most of the CF patients regularly seen in CF care centres in France. It is based on a yearly questionnaire that collects demographic, clinical and social data for every $\mathrm{CF}$ patient seen during that period. Consent to collect and analyse the data was obtained from the adult patients or the children's parents, at first inclusion in the registry [9].

The first step of the analysis was to extract genotypic data on all the CF patients carrying at least one of the $3849+10 \mathrm{kbC}->\mathrm{T}$ or $2789+5 \mathrm{G}->\mathrm{A}$ alleles, who attended a participating care centre anytime between 1992 and 2002.

\section{AFFLLIATIONS}

Laboratoire d'Histologie, Embryologie et Cytogénétique Faculté de Médecine et des Sciences de la Santé, Université de Bretagne Occidentale \& INSERM - U613, Brest, France.

\section{CORRESPONDENCE}

M. De Braekeleer

Laboratoire de Cytogénétique

Faculté de Médecine et des Sciences de la Santé

Université de Bretagne Occidentale 22

avenue Camille Desmoulins

CS 93837

F-29238 Brest cedex 3

France

Fax: 33298018189

E-mail: marc.debraekeleer@univbrest.fr

Received:

August 282004

Accepted after revision:

November 182004

\section{SUPPORT STATEMENT}

I. Duguépéroux is the recipient of a post-doctoral fellowship from "Vaincre la Mucoviscidose" (Paris, France). This work was supported by a grant from "Vaincre la

Mucoviscidose", owner of the French CF Registry.

European Respiratory Journal Print ISSN 0903-1936 Online ISSN 1399-3003 
Secondly, the available data were extracted for all patients who were compound heterozygous for $3849+10 \mathrm{kbC}->\mathrm{T} / \Delta \mathrm{F} 508$ or $2789+5 \mathrm{G}->\mathrm{A} / \Delta \mathrm{F} 508$, as previously described [10-12]. This analysis was based on a multi-centre study, with each $\mathrm{CF}$ centre being responsible for its own measurements and with the knowledge that patients from a same centre are tested with the same equipment. Each patient was matched to a patient homozygous for the $\Delta$ F508 mutation, of same sex and age $( \pm 1 \mathrm{yr}$ ), having consulted at the same CF care centre. All the data were obtained from the 2000 investigation, except for clinical events that were compiled over the previous $7 \mathrm{yrs}$ (1994-2000).

The mean and median ages on January 1,2001, and at the time of diagnosis were exact ages expressed as years $\pm \mathrm{SD}$. The age at diagnosis was defined as the age at the time when, based on the clinical and biochemical results and the clinical evolution, the diagnosis became evident. Patients diagnosed following antenatal diagnosis and/or neonatal screening were excluded from the calculation. The sweat chloride concentration was measured at the time of diagnosis in the CF care centre and expressed as $\mathrm{mEq} \cdot \mathrm{L}^{-1}$. A sweat chloride concentration $>60 \mathrm{mEq} \cdot \mathrm{L}^{-1}$ was considered positive [13]. The pulmonary function and physical status were measured in each CF centre. The pulmonary status was assessed by tests of forced vital capacity (FVC) and forced expiratory volume in one second (FEV1). The measures were expressed as a percentage of predicted values for sex, age and height according to standardised tables [14]. The Z-scores of weight or height according to sex and age were calculated, using the French population as a reference [15]. A negative Z-score is synonymous with growth retardation. The body mass index (BMI) was also calculated for each patient and expressed in $\mathrm{kg} \cdot \mathrm{m}^{-2}$, the normal values being included between 20 and 25. A faecal fat-balance study was performed to evaluate the exocrine pancreatic status. A steatocrit test or elastase measurement was also performed. The status at diagnosis consisted of symptoms that prompted the parents or the individuals to consult a physician. The occurrence of several common complications of $\mathrm{CF}$, including liver cirrhosis, diabetes mellitus, distal intestinal obstructive syndrome, recurrent pancreatitis, rectal prolapse or nasal polyposis was used to define the clinical status since 1994.

Descriptive data, expressed as mean values with indication of SD, were analysed through an ANOVA for parametric variables. Categorical variables, expressed as the number of patients in each cell, were compared using the H KruskalWallis test (equivalent to Chi-squared test) for two groups as being nonparametric variables. The significant level was set at $p \leqslant 0.05$.

\section{RESULTS}

Since the creation of the French CF registry in 1992, 39 CF patients (23 males, 16 females) carrying at least one $3849+$ $10 \mathrm{kbC}->\mathrm{T}$ allele have been registered (table 1). During the 1992-2002 period, one female bearing the $3849+10 \mathrm{kbC}->\mathrm{T} / \Delta \mathrm{F} 508$ genotype was lost to follow-up at the age of $28 \mathrm{yrs}$, and three patients (two females and one male) died of respiratory problems at a mean age of 35.4 yrs. The genotype was fully identified for 38 out of the 39 patients (table 1). Two genotypes accounted for almost $80 \%$ of the patients,

\begin{tabular}{|c|c|c|}
\hline TABLE 1 & $\begin{array}{l}\text { Genotypes identified } \\
\text { patients sharing the } 3 \\
2789+5 G->\text { A mutation }\end{array}$ & $\begin{array}{l}\text { stic fibrosis } \\
\text { C- }>\text { T or the }\end{array}$ \\
\hline Genotypes & $3849+10 k b C->T$ & $2789+5 G->A$ \\
\hline$\Delta \mathbf{1 5 0 7}$ & & 2 \\
\hline$\Delta \mathrm{F} 508$ & 27 & 61 \\
\hline $1525-1 G->A$ & 1 & \\
\hline $1717-1 G>A$ & & 1 \\
\hline $2183 A A>G$ & & 3 \\
\hline 3129del4 & & 1 \\
\hline 3659delC & & 1 \\
\hline G542X & 4 & 6 \\
\hline G551D & & 1 \\
\hline G970R & & 2 \\
\hline G1244E & 2 & \\
\hline L558S & & 1 \\
\hline M1V & 1 & \\
\hline N1303K & & 1 \\
\hline R347P & 1 & \\
\hline R553X & 1 & 1 \\
\hline R1066C & & 1 \\
\hline S1251N & 1 & \\
\hline Unknown & 1 & 6 \\
\hline Total & 39 & 88 \\
\hline
\end{tabular}

$3849+10 \mathrm{kbC}->\mathrm{T} / \Delta \mathrm{F} 508(\mathrm{n}=27,69.2 \%)$ and $3849+10 \mathrm{kbC}->\mathrm{T} /$ G542X $(n=4,10.3 \%)$, and two siblings shared the G1244E allele $(5.2 \%)$. A total of 36 patients were alive on January 1 , 2003. The mean and median ages of the living patients were 22.3 and 23.3 yrs, respectively.

Sixteen (10 males, six females) out of the 27 patients sharing the $3849+10 \mathrm{kbC}->\mathrm{T} / \Delta \mathrm{F} 508$ genotype were seen at least once in 2000 and were included in the genotype-phenotype study (table 2$)$. The mean age was similar in both groups $(\mathrm{p}>0.05)$. Ten $(62.5 \%) 3849+10 \mathrm{kbC}->\mathrm{T} / \Delta \mathrm{F} 508$ patients were older than 15 yrs. None had died during the study period. A $3849+10 \mathrm{kbC}-$ $>\mathrm{T} / \Delta \mathrm{F} 508$ patient received a bipulmonary transplant, while another aged 23 yrs was on the transplantation waiting list.

The mean age at diagnosis was significantly higher among the $3849+10 \mathrm{kbC}->\mathrm{T} / \Delta \mathrm{F} 508$ patients than among those homozygous for the $\Delta \mathrm{F} 508$ mutation $(12.7 \pm 9.6$ versus $3.1 \pm 5.1 \mathrm{yrs}$, $\mathrm{p}=0.002)$. The mean sweat chloride concentration was close to normal values in the compound heterozygote group, whereas it was much higher in the $\Delta \mathrm{F} 508$ homozygote group (67.9 versus 110.4, $\mathrm{p}<0.0001)$. All $3849+10 \mathrm{kbC}->\mathrm{T} / \Delta \mathrm{F} 508$ patients but one had respiratory problems at the time of diagnosis, while the $\Delta \mathrm{F} 508$ homozygotes were more likely to have intestinal problems, including four patients with meconium ileus versus none among the compound heterozygotes $(\mathrm{p}=0.03)$.

The mean anthropometric values were similar in both groups; the mean BMI was under the lower normal bracket. Although only borderline significant, lung function was definitely better in the $3849+10 \mathrm{kbC}->\mathrm{T} / \Delta \mathrm{F} 508$ group (FEV1 $83.0 \%$ and FVC $91.6 \%$ pred) than in the $\Delta \mathrm{F} 508$ homozygote group (FEV1 $59.9 \%$ 


\begin{tabular}{|c|c|c|c|c|}
\hline \multirow[t]{2}{*}{ TABLE 2} & \multicolumn{4}{|c|}{$\begin{array}{l}\text { Characteristics of the patients compound } \\
\text { heterozygous for the } 3849+10 \mathrm{kbC}->\mathrm{T} / \Delta \mathrm{F} 508 \\
\text { mutations, compared to homozygotes for the } \\
\Delta \mathrm{F} 508 \text { mutation }\end{array}$} \\
\hline & & $\begin{array}{c}3849+10 k b C- \\
>T / \Delta F 508\end{array}$ & $\begin{array}{l}\Delta \mathrm{F} 508 / \\
\Delta \mathrm{F} 508\end{array}$ & $\begin{array}{c}\mathrm{p}- \\
\text { values }\end{array}$ \\
\hline Sex males/fe & nales & $10 / 6$ & $10 / 6$ & \\
\hline \multicolumn{5}{|c|}{ Age on January 012001 yrs } \\
\hline Mean \pm SD & & $19.6 \pm 10.2$ & $19.6 \pm 10.2$ & NS \\
\hline Median & & 19.5 & 19.0 & \\
\hline Range & & $5-47$ & $5-47$ & \\
\hline \multicolumn{5}{|c|}{ Age at diagnosis yrs ${ }^{\#}$} \\
\hline Mean $\pm S D$ & & $12.7 \pm 9.6$ & $3.1 \pm 5.1$ & 0.002 \\
\hline Median & & 11.8 & 0.8 & \\
\hline Range & & $0.6-34.0$ & $0.0-16.8$ & \\
\hline \multicolumn{5}{|c|}{ Sweat chloride conc. $\mathrm{mEq} \cdot \mathrm{L}^{-1}$} \\
\hline Mean \pm SD & & $67.9 \pm 19.8$ & $110.4 \pm 17.4$ & $<0.0001$ \\
\hline Median & & 67.0 & 116.5 & \\
\hline Range & & $45.0-95.0$ & $77.0-135.0$ & \\
\hline Pancreatic in & sufficiency \% & 46.6 & 100.0 & 0.002 \\
\hline \multicolumn{5}{|c|}{ Sputum cultures } \\
\hline H. influenzaє & & 5 & 5 & NS \\
\hline S. aureus & & 10 & 8 & NS \\
\hline$P$. aeruginos & & 16 & 8 & NS \\
\hline \multicolumn{5}{|c|}{ Status at diagnosis } \\
\hline Family histo & & 4 & 2 & NS \\
\hline Meconium il & & 0 & 4 & 0.03 \\
\hline Diarrhoea & & 1 & 6 & 0.03 \\
\hline Respiratory & symptoms & 15 & 9 & 0.01 \\
\hline \multicolumn{5}{|c|}{ Physical status } \\
\hline Height Z-sce & re mean $\pm \mathrm{SD}$ & $-0.270 \pm 0.660$ & $-0.850 \pm 1.412$ & NS \\
\hline Weight Z-sc & ore mean \pm SD & $-0.540 \pm 1.112$ & $-1.214 \pm 1.583$ & NS \\
\hline $\mathrm{BMI} \mathrm{kg} \cdot \mathrm{m}^{-2}$ & nean $\pm S D$ & $16.28 \pm 3.26$ & $16.11 \pm 3.00$ & NS \\
\hline \multicolumn{5}{|c|}{ Lung function $\%$ pred } \\
\hline FEV1 mean & SD (median) & $83.04 \pm 12.08(81.0)$ & $59.86 \pm 21.11(64.3)$ & 3) 0.069 \\
\hline FVC mean \pm & SD (median) & $91.60 \pm 8.19(93.4)$ & $76.96 \pm 20.80(74.2)$ & p) 0.082 \\
\hline \multicolumn{5}{|c|}{ Clinical events since 1994} \\
\hline No morbidit & & 8 & 3 & 0.01 \\
\hline Liver cirrhos & & 0 & 1 & NS \\
\hline Haemoptysi & & 4 & 1 & 0.069 \\
\hline Nasal polyp & & 2 & 2 & NS \\
\hline Pregnancy/p & aternity & 5 & 0 & 0.01 \\
\hline
\end{tabular}

Conc.: concentration; H. influenzae: Haemophilus influenzae; S. aureus: Staphylococcus aureus; P. aeruginosa: Pseudomonas aeruginosa; BMl: body mass index; FEV1: forced expiratory volume in one second; FVC: forced vital capacity; NS: nonsignificant. ${ }^{\#}$ : neonatal screening and antenatal diagnosis excluded.

and FVC $76.9 \%$ pred). No difference was found in the prevalence of pathogens between both groups $(\mathrm{p}>0.05)$.

Pancreatic insufficiency was present in seven out of the 15 (46.6\%) 3849+10kbC->T / $\Delta$ F508 patients for whom the status was known, while all $16 \Delta \mathrm{F} 508 / \Delta \mathrm{F} 508$ patients were pancreatic insufficient $(p=0.02)$. Morbidity was lower among the $3849+10 \mathrm{kbC}->\mathrm{T} / \Delta \mathrm{F} 508$ patients $(\mathrm{p}<0.01)$, with no patient with liver cirrhosis or diabetes mellitus. Five out of the 16 compound heterozygotes had had children versus none among their matched peers.

Since the French CF registry was implemented in 1992, $88 \mathrm{CF}$ patients (44 males, 44 females) bearing the $2789+5 \mathrm{G}->\mathrm{A}$ mutation have been registered (table 1). During the 19922002 period, four adult patients (two males and two females) were lost to follow-up, and two (one male and one female) died at 42 and $37 \mathrm{yrs}$, respectively. The genotype was fully identified for 82 out of the 88 patients. Three genotypes accounted for almost $80 \%$ of the patients: $2789+5 \mathrm{G}->\mathrm{A} / \Delta \mathrm{F} 508$ $(n=61,69.3 \%), 2789+5 G->A / G 542 X(n=6,6.8 \%)$ and $2789+5 G-$ $>$ A $/ 2183 \mathrm{AA}->\mathrm{G}(\mathrm{n}=3,3.4 \%)$. A total of 82 patients $(93.2 \%)$ were alive on January 1, 2003. The mean and median ages of the living patients were 25.1 and 23.7 yrs, respectively.

Thirty-four patients (16 males, 18 females) carrying the $2789+5 \mathrm{G}->\mathrm{A} / \Delta \mathrm{F} 508$ genotype and seen in 2000 were included in the genotype-phenotype study (table 3 ). The mean age was similar in both groups $(26.26 \pm 11.3 \mathrm{yrs}), 25$ of them $(73.5 \%)$ being older than 15 yrs. No patient died during the study period.

The mean age at diagnosis was significantly higher among the $2789+5 \mathrm{G}->\mathrm{A} / \Delta \mathrm{F} 508$ patients than among those homozygous for the $\Delta \mathrm{F} 508$ mutation $(16.6 \pm 12.7$ versus $4.5 \pm 8.9 \mathrm{yrs}$, $\mathrm{p}=0.0001$ ). The mean sweat chloride concentration was high in both groups, with no statistically significant difference. The $2789+5 G->A / \Delta F 508$ patients had very few gastrointestinal symptoms at the time of diagnosis. None had meconium ileus $(p=0.01)$ and only two had malnutrition or diarrhoea, respectively $(p=0.03$ and $p=0.001)$. Conversely, they had an increased frequency of nasal polyposis compared with the $\Delta$ F508 homozygotes $(\mathrm{p}=0.02)$.

The anthropometric values were better among the compound heterozygotes, with the mean Z-score for weight and the BMI within normal ranges. Lung function was also better in the $2789+5 \mathrm{G}->\mathrm{A} / \Delta \mathrm{F} 508$ group; however, only the difference in the mean FEV1 between both groups reached statistical significance $(p=0.03)$. The median values for FEV1 and FVC were higher among those patients carrying the $2789+5$ G- $>$ A mutation (80.8 versus $57.9 \%$ and $94.8 \%$ versus $80.8 \%$, respectively).

The sputum culture results showed significant differences between those compound heterozygotes for the $2789+5 \mathrm{G}->\mathrm{A}$ mutation and those homozygous for the $\Delta \mathrm{F} 508$ allele, the former having an increased prevalence of Haemophilus influen$z a e(\mathrm{p}=0.002)$ and Staphyloccocus aureus $(\mathrm{p}=0.004)$, but a lower prevalence of Pseudomonas aeruginosa $(\mathrm{p}=0.00005)$.

Pancreatic insufficiency was present in 19 out of the 32 (59.4\%) $2789+5 \mathrm{G}->\mathrm{A} / \Delta \mathrm{F} 508$ patients for whom the status was known, while 32 out of $33(97.0 \%) \Delta \mathrm{F} 508 / \Delta \mathrm{F} 508$ patients were pancreatic insufficient $(\mathrm{p}=0.002)$. Morbidity was also lower, with no patient having liver cirrhosis or diabetes mellitus.

\section{DISCUSSION}

As first described by HighSMith et al. [16] in 1994, the $3849+10 \mathrm{kbC}->\mathrm{T}$ mutation was identified in 13 patients with chronic pulmonary disease but normal sweat chloride values. It is due to the insertion of $10 \mathrm{~kb}$ in intron 19 , inducing a $\mathrm{C}$ to $\mathrm{T}$ 


\begin{tabular}{|c|c|c|c|c|}
\hline \multirow[t]{2}{*}{ TABLE 3} & \multicolumn{4}{|c|}{$\begin{array}{l}\text { Characteristics of the patients compound } \\
\text { heterozygous for the } 2789+5 \mathrm{G}->\mathrm{A} / \Delta \mathrm{F} 508 \\
\text { mutations, compared with homozygotes for the } \\
\Delta \mathrm{F} 508 \text { mutation }\end{array}$} \\
\hline & & $\begin{array}{l}2789+5 G- \\
>A / \Delta F 508\end{array}$ & $\begin{array}{l}\Delta F 508 / \\
\Delta F 508\end{array}$ & $\begin{array}{c}\mathrm{p}- \\
\text { values }\end{array}$ \\
\hline Sex males/fe & males & $16 / 18$ & $16 / 18$ & \\
\hline \multicolumn{5}{|c|}{ Age on January 012001 yrs } \\
\hline Mean \pm SD & & $26.3 \pm 11.4$ & $26.2 \pm 11.3$ & NS \\
\hline Median & & 26.0 & 26.0 & \\
\hline Range & & $5-51$ & $5-47$ & \\
\hline \multicolumn{5}{|c|}{ Age at diagnosis yrs ${ }^{\#}$} \\
\hline Mean $\pm S D$ & & $16.6 \pm 12.7$ & $4.5 \pm 8.9$ & 0.0001 \\
\hline Median & & 15.8 & 0.8 & \\
\hline Range & & $0.2-46.5$ & $0.08-35.3$ & \\
\hline \multicolumn{5}{|c|}{ Sweat chloride conc. $\mathrm{mEq} \cdot \mathrm{L}^{-1}$} \\
\hline Mean \pm SD & & $104.4 \pm 25.1$ & $115.3 \pm 22.5$ & NS \\
\hline Median & & 106.0 & 119.0 & \\
\hline Range & & $62.0-150.0$ & $77.0-155.0$ & \\
\hline Pancreatic i & sufficiency $\%$ & 59.4 & 97.0 & 0.002 \\
\hline \multicolumn{5}{|c|}{ Sputum cultures } \\
\hline H. influenze & & 13 & 3 & 0.002 \\
\hline S. aureus & & 26 & 17 & 0.004 \\
\hline$P$. aerugino & & 8 & 25 & 0.00005 \\
\hline \multicolumn{5}{|c|}{ Status at diagnosis } \\
\hline Meconium & eus & 0 & 5 & 0.01 \\
\hline Malnutrition & & 2 & 8 & 0.03 \\
\hline Diarrhoea & & 2 & 13 & 0.001 \\
\hline Nasal poly & osis & 5 & 0 & 0.02 \\
\hline Respiratory & symptoms & 20 & 15 & NS \\
\hline \multicolumn{5}{|c|}{ Physical status } \\
\hline Height Z-sc & ore mean $\pm \mathrm{SD}$ & $-0.19 \pm 0.97$ & $-0.60 \pm 1.07$ & NS \\
\hline Weight Z-s & ore mean $\pm S D$ & $0.36 \pm 2.01$ & $-0.73 \pm 1.61$ & 0.02 \\
\hline $\mathrm{BMI} \mathrm{kg} \cdot \mathrm{m}^{-2}$ & mean $\pm S D$ value & $20.2 \pm 3.5$ & $18.8 \pm 2.7$ & NS \\
\hline \multicolumn{5}{|c|}{ Lung function \% pred } \\
\hline \multicolumn{2}{|c|}{$\mathrm{FEV} 1$ mean $\pm \mathrm{SD}$ (median) } & \multicolumn{3}{|c|}{$75.38 \pm 29.69$ (80.8) $59.06 \pm 24.87$ (57.9) 0.03} \\
\hline FVC mean & -SD (median) & \multicolumn{3}{|c|}{$89.03 \pm 27.07$ (94.8) $78.03 \pm 22.80$ (80.8) NS } \\
\hline \multicolumn{5}{|c|}{ Clinical events since 1994} \\
\hline Liver cirrho & & 0 & 6 & 0.016 \\
\hline Diabetes $\mathrm{m}$ & ellitus & 0 & 2 & NS \\
\hline DIOS & & 0 & 2 & NS \\
\hline Nasal poly & osis & 8 & 8 & NS \\
\hline \multicolumn{5}{|c|}{$\begin{array}{l}\text { Conc.: concentration; H. influenzae: Haemophilus influenzae; S. aureus: } \\
\text { Staphylococcus aureus; P. aeruginosa: Pseudomonas aeruginosa; BMI: body } \\
\text { mass index; FEV1: forced expiratory volume in one second; FVC: forced vital } \\
\text { capacity; DIOS: distal intestinal obstructive syndrome; NS: nonsignificant. \#: } \\
\text { neonatal screening and antenatal diagnosis excluded. }\end{array}$} \\
\hline
\end{tabular}

change and leading to the creation of an alternative splice acceptor site.

The Cystic Fibrosis database reports that the worldwide frequency of the $3849+10 \mathrm{kbC}->\mathrm{T}$ mutation is close to $0.2 \%$ of all CF chromosomes [4]. In Europe, its frequency is $0.15 \%$ of $\mathrm{CF}$ chromosomes, although it is more common among Jews from eastern Europe and in the Polish population $(\sim 4 \%$ of $\mathrm{CF}$ alleles) [17-20]. A higher frequency $(\sim 2 \%)$ is also reported in
Hispanic and Native American patients [21, 22]. The $3849+10 \mathrm{kbC}->\mathrm{T}$ mutation was found to be associated with four microsatellite haplotypes in Europe, while a fifth haplotype was identified in the Native American population, consistent with the hypothesis of a recurrent mutation [22, 23].

In the population presented here, $39.3 \%$ of the patients, for whom the birthplace was registered, were from the north-east region of France (Nord-Pas-de-Calais and Lorraine), where 300,000 Polish individuals settled between 1921 and 1938, and where, nowadays, one in eight inhabitants has Polish roots. Unfortunately, microsatellite haplotypes of patients are not available in the French CF registry, in order to check the homogeneity of the $3849+10 \mathrm{kbC}->\mathrm{T}$ mutation in this population.

AUGARTEN et al. [24] previously investigated $15 \mathrm{CF}$ patients carrying the $3849+10 \mathrm{kbC}->\mathrm{T}$ allele and compared their clinical status with that of an unmatched group of 57 patients who were compound heterozygous or homozygous for the $\Delta \mathrm{F} 508$ or W1282X mutations. Patients with the $3849+10 \mathrm{kbC}->\mathrm{T}$ mutation were older and had been diagnosed at a more advanced age. They were more likely to be pancreatic sufficient (PS), and have no diabetes mellitus or liver cirrhosis. They were in a better nutritional but not pulmonary state.

GILBERT et al. [25] also reported the clinical spectrum of CF among 14 patients who were compound heterozygous or homozygous for the $3849+10 \mathrm{kbC}->\mathrm{T}$ mutation, without matching them to $\Delta \mathrm{F} 508$ homozygotes. The age at diagnosis ranged 2-32 yrs. Half of the patients were PS, the sweat chloride concentration being within normal values in seven patients. Lung disease varied from mild to severe.

In 1995, STERN et al. [26] reported eight patients who were compound heterozygous for the $3849+10 \mathrm{kbC}->\mathrm{T}$ mutation. All had normal or borderline sweat chloride values, were PS, but had a variable pulmonary disease ranging from mild to severe. FELDMANN et al. [27] collected data on CF patients with normal or borderline sweat chloride levels and two CFTR mutated alleles. One fourth carried the $3849+10 \mathrm{kbC}->\mathrm{T}$ allele, which was the most frequent allele observed in the study. None had sweat test values $>60 \mathrm{mmol} \cdot \mathrm{L}^{-1}$ (range 18-55.5), but all had pulmonary symptoms. Five of them had been diagnosed at age 20 yrs or over.

The $2789+5 \mathrm{G}->\mathrm{A}$ allele was also first described by HiGHSMITH et al. [28]. A G to A substitution was observed at nucleotide 2,789 in a splice donor site (intron 14b), leading to an mRNA splicing, class 5 mutation. Apart from the consanguineous family in which the mutation was first described, no clinical evaluation of the $2789+5 \mathrm{G}->\mathrm{A} / \Delta \mathrm{F} 508$ genotype was found in the literature. This mutation accounts for $0.1 \%$ of the $\mathrm{CF}$ chromosomes worldwide. In Europe, EsTIVILL et al. [17] found a high frequency in the south of Greece (4.5\% of chromosomes), whereas, in France, Claustres et al. [29] found it to be more frequent in the north $(2.87 \%)$ than near the Mediterranean coast. In the current population, 30 out of the 65 patients $(46.1 \%)$ for whom the birth place was known were from the north-east region of France.

This appears to be the first study in which $3849+10 \mathrm{kbC}->\mathrm{T} /$ $\Delta \mathrm{F} 508$ or $2789+5 \mathrm{G}->\mathrm{A} / \Delta \mathrm{F} 508$ patients were matched to $\Delta \mathrm{F} 508$ 
homozygotes. Both groups were associated with delayed diagnosis and a higher frequency of pancreatic sufficiency. Although they had high sweat chloride values, patients carrying the $2789+5 \mathrm{G}->\mathrm{A}$ allele had a milder phenotype, characterised by better anthropometric and lung function measures, less colonisation with $P$. aeruginosa and, probably, a higher life expectancy. Patients carrying the $3849+10 \mathrm{kbC}->\mathrm{T}$ mutation also appeared to have a milder phenotype, with better anthropometric and lung function measures.

Both populations $(3849+10 \mathrm{kbC}->\mathrm{T} / \Delta \mathrm{F} 508$ and $2789+5 \mathrm{G}->\mathrm{A} /$ $\Delta F 508)$ also appeared to differ from the other patients included in the French CF registry. Indeed, the mean and median ages at the time of diagnosis of the overall population were, respectively, 2.8 yrs and 4 months; the mean and median ages of the registered population were 14.9 and 13 yrs. Moreover, the proportion of the adults with the $3849+10 \mathrm{kbC}->\mathrm{T} / \Delta \mathrm{F} 508$ or $2789+5 \mathrm{G}->\mathrm{A} / \Delta \mathrm{F} 508$ genotype was increased: $>50 \%$ were 18 yrs, compared with $35.5 \%$ of the patients included in the registry [30]. The results presented here also show that the $3849+10 \mathrm{kbC}->\mathrm{T} / \Delta \mathrm{F} 508$ and $2789+5 \mathrm{G}->\mathrm{A} / \Delta \mathrm{F} 508$ populations are closed to $\mathrm{CF}$ adults with delayed diagnosis [31-33]. In fact, the $3849+10 \mathrm{kbC}->\mathrm{T} / \Delta \mathrm{F} 508$ or $2789+5 \mathrm{G}->\mathrm{A} / \Delta \mathrm{F} 508$ genotype can be included in the adult group defined by HuBERT et al. [8] as patients with expected partly functional CFTR corresponding to at least one "mild" mutation. In these patients, the age at diagnosis is $>20$ yrs with no meconium ileus, less pancreatic insufficiency but respiratory problems.

Several differences, although large, with the $\Delta$ F508 homozygotes did not reach statistical significance. This could be due to the small numbers of patients included in this multi-centre study or to the high variation sometimes observed within the $\Delta$ F508 homozygous group. One way to overcome this last problem would have been to partner each compound heterozygous patient to three $\Delta \mathrm{F} 508 / \Delta \mathrm{F} 508$ patients matched for sex, age and care centre, and to perform the statistical analysis on the "mean $\Delta$ F508 homozygote population". Unfortunately, this was impossible, due to the difficulty of finding more than one peer, especially in older age groups (the oldest $2789+5 \mathrm{G}->\mathrm{A} /$ $\Delta \mathrm{F} 508$ patient included in the present study was $51 \mathrm{yrs}$ ).

Despite these difficulties, it can be concluded that both $3849+10 \mathrm{kbC}->\mathrm{T}$ and $2789+5 \mathrm{G}->\mathrm{A}$ mutations are associated with a milder course of cystic fibrosis disease. The reasons for such moderate disease can probably be found in the nature of the mutations. The $3849+10 \mathrm{kbC}->\mathrm{T}$ and $2789+5 \mathrm{G}->\mathrm{A}$ alleles are splice site mutations leading to abnormal mRNA; however, small amounts of normally spliced transcripts are also detected (4-8\% of that found in normal individuals) [16, 28]. The presence of these small amounts of normal cystic fibrosis transmembrane receptor protein in the cystic fibrosis patients carrying the $3849+10 \mathrm{kbC}->\mathrm{T}$ or $2789+5 \mathrm{G}->\mathrm{A}$ mutation is likely to be responsible for a milder disease and a better life expectancy.

\section{ACKNOWLEDGEMENTS}

The authors would like to thank the participating centres to the French CF Registry that contributed data and the team in charge of the management of this registry at Institut National d'Etudes Démographiq̀ues (INED; Paris, France).

\section{REFERENCES}

1 Rommens JM, Iannuzzi MC, Kerem BS, et al. Identification of the cystic fibrosis gene: chromosome walking and jumping. Science 1989; 245: 1059-1065.

2 Riordan JR, Rommens JM, Kerem BS, et al. Identification of the cystic fibrosis gene: cloning and characterization of complentary DNA. Science 1989; 245: 1066-1073.

3 Kerem BS, Rommens JM, Buchanan JA, et al. Identification of the cystic fibrosis gene: genetic analysis. Science 1989; 245: 1073-1080.

4 International Cystic Fibrosis Genetics Research Community. Cystic fibrosis mutation database. http:// genet.sickkids.on.ca/cftr/ Date last updated: continuous.

5 The Cystic Fibrosis Genotype-Phenotype Consortium. Correlation between genotype and phenotype in patients with cystic fibrosis. N Engl J Med 1993; 329: 1308-1313.

6 Gan KH, Heijerman HGM, Bakker W. Correlation between genotype and phenotype in patients with cystic fibrosis. $N$ Engl J Med 1994; 330: 865-866.

7 Kraemer R, Birrer P, Liechti-Gallati S. Genotype-phenotype association in infants with cystic fibrosis at the time of diagnosis. Pediatr Res 1998; 44: 920-926.

8 Hubert D, Bienvenu T, Desmazes-Dufeu N, et al. Genotype-phenotype relationships in a cohort of adult cystic fibrosis patients. Eur Respir J 1996; 9: 2207-2214.

9 De Braekeleer M, Bellis G. Observatoire national de la mucoviscidose (ONM): structure de l'observatoire et résultats de l'enquête 1999 [Observatoire national de la mucoviscidose (ONM): structure of the registry and results from the 1999 enquiry]. Référence Mucoviscidose 2001; 6: $42-48$

10 De Braekeleer M, Allard C, Leblanc J-P, Simard F, Aubin G. Genotype-phenotype correlation in cystic fibrosis patients compound heterozygous for the A455E mutation. Hum Genet 1997; 101: 208-211.

11 Duguépéroux I, Bellis G, Férec C, Gillet D, Scotet V, De Braekeleer M. Relationship between genotype and phenotype for the CFTR gene W846X mutation. J Med Genet 2002; 39: E32.

12 Duguépéroux I, Bellis G, Lesure JF, Renouil M, Flodrops H, De Braekeleer M. Cystic fibrosis at the Reunion Island (France): spectrum of mutations and genotype-phenotype for the Y122X mutation. J Cyst Fibros 2004; 3: 185-188.

13 Welsh MJ, Tsui LC, Boat TF, Beaudet AL. Cystic fibrosis. In: Scriver CR, Beaudet AL, Sly WS, Valle D, eds. The Metabolic Basis of Inherited Disease. New York, McGrawHill, 1995; pp. 3799-3876.

14 Knudson RJ, Lebowitz MD, Holberg CJ, Burrows B. Changes in the normal expiratory flow-volume curve with growth and aging. Am Rev Respir Dis 1983; 127: 725-734.

15 Sempé M. Auxologie - méthode et séquences. Méditions, Lyon, 1997.

16 Highsmith WE, Burch LH, Zhou Z, et al. A novel mutation in the cystic fibrosis gene in patients with pulmonary disease but normal sweat chloride concentrations. $N$ Engl J Med 1994; 331: 974-980.

17 Estivill X, Bancells C, Ramos C, Biomed CF mutation Analysis Consortium. Geographic distribution and regional origin of 272 cystic fibrosis mutations in European populations. Hum Mutat 1997; 10: 135-154. 
18 Abeliovich D, Lavon IP, Lerer I, et al. Screening for five mutations detects $97 \%$ of cystic fibrosis (CF) chromosomes and predicts a carrier frequency of 1:29 in the Jewish Ashkenazi population. Am J Hum Genet 1992; 51: 951-956.

19 Czerska K, Sobczynska-Tomaszewska A, Bal J. Frequency of occurring of the $3849+10 \mathrm{~kb} C>\mathrm{T}$ mutation in Polish CF patients is significantly higher than in most of other populations. J Cyst Fibros 2004; 3: Suppl. 2, S8.

20 Witt M, Pogorzelski A, Bal J, Rutkiewicz E, Majka L, Sobczynska A. Frequency of mutations and genotypes of the CFTR gene in cystic fibrosis adults in Poland. Pneumonol Alergol Pol 1999; 67: 137-141.

21 Liang MH, Wertz KK, Bowman CM, Hsu E, Shapiro B, Wong LJC. $3849+10 \mathrm{~kb}$ C- $>$ T splicing mutation in Hispanic CF patients. Mol Genet Metab 1998; 64: 213-216.

22 Mercier B, Raguénès $\mathrm{O}$, Estivill $\mathrm{X}$, et al. Complete detection of mutations in cystic fibrosis patients of Native American origin. Hum Genet 1994; 94: 629-632.

23 Morral N, Llevadot R, Casals $\mathrm{T}$, et al. Independent origins of cystic fibrosis mutations R334W, R347P, R1162X, and $3849+10 \mathrm{kbC}->\mathrm{T}$ provide evidence of mutation recurrence in the CFTR gene. Am J Hum Genet 1994; 55: 890-898.

24 Augarten A, Kerem BS, Yahav Y, et al. Mild cystic fibrosis and normal or borderline sweat test in patients with the 3849+0kb C->T mutation. Lancet 1993; 342: 25-26.

25 Gilbert F, Li Z, Arzimanoglou I, et al. Clinical spectrum in homoygotes and compound heterozygotes inheriting cystic fibrosis mutation $3849+10 \mathrm{~kb}$ C $>$ T: Significance for geneticists. Am J Med Genet 1995; 58: 356-359.
26 Stern RC, Doershuk CF, Drumm ML. 3839+10kb C->T mutation and disease severity in cystic fibrosis. Lancet 1995; 346: 274-276.

27 Feldmann D, Couderc R, Audrezet MP, et al. CFTR genotypes in patients with normal or borderline sweat chloride levels. Hum Mutat 2003; 22: 340-347.

28 Highsmith WEJ, Burch LH, Zhou Z, et al. Identification of a splice site mutation $(2789+5 \mathrm{G}->\mathrm{A})$ associated with small amounts of normal CFTR mRNA and mild cystic fibrosis. Hum Mutat 1997; 9: 332-338.

29 Claustres M, Guittard C, Bozon D, et al. Spectrum of CFTR mutations in cystic fibrosis and in congenital absence of the vas deferens in France. Hum Mutat 2000; 16: 143-156.

30 Muco 2000. Rapport sur la situation de la mucoviscidose en France en 2000 [Report on the cystic fibrosis situation in France in 2000]. Paris, Vaincre la Mucoviscidose et Institut National d'Etudes Démographiques, 2002.

31 Gan KH, Geus WP, Bakker W, Lamers CBHW, Heijerman HGM. Genetic and clinical features of patients with cystic fibrosis diagnosed after the age of 16 years. Thorax 1995; 50: 1301-1304.

32 Widerman E, Millner L, Sexauer W, Fiel S. Health status and sociodemographic characterisitics of adults receiving a cystic fibrosis diagnosis after age 18 years. Chest 2000; 118: 427-433.

33 Gilljam M, Ellis L, Corey M, Zielanski J, Durie P, Tullis DE. Clinical manifestations of cystic fibrosis among patients with diagnosis in adulthood. Chest 2004; 126: 1215-1224. 